\title{
糖溶液に対する中学生および成人の好みの分析
}

\section{Analysis of Liking for Sugar Solutions in Junior High School Students and Adults}

\author{
加藤 佳子·井川 佳 子 \\ (広島大学) \\ Yoshiko Katou, Yoshiko Ikawa \\ Hiroshima University, 1-1-1, Kagamiyama, \\ Higashihiroshima-shi, Hiroshima, 739-8524 \\ ₹739-8524 広島県東広島市鏡山 1-1-1
}

\begin{abstract}
Liking for 4 levels of sucrose solution $(2.5 \%, 5.0 \%, 10.0 \%, 20.0 \%)$ and 3 kinds of sugar solution having different taste qualities of sweetness were investigated using sensory evaluation in junior high school students and adults (290 subjects). The questionnaire survey including affection, cognition, liking and consumption of sweets was conducted in the same subjects and the relation between response and liking for sugar solutions was examined.

Analysis of variance showed that age was the important factor influencing the liking for sucrose concentration. Junior high school students and elderly adults $(60+$ years $)$ were inclined to like higher sucrose concentrations and not to like lower sucrose concentration. The young middle-aged subjects (30-39 years) liked low sucrose concentration and did not like high sucrose concentration compared to the distribution of liking in other age groups. It was considered that there was a turning point in sweetness preference in this middle age-group. Females liked $2.5 \%$ sucrose solution better than males. Affection for sweets influenced the choice of sucrose concentration, while cognition of sweets had no effect on the liking for sucrose concentration. The degree of liking or eating sweets and the preference of intensity in seasoning also related to the choice of sucrose concentration. Liking for sugar solutions with different taste qualities did not relate to age or sex.
\end{abstract}

\section{1. 緒言}

人は生来，甘味を好む傾向を持って抢り，多くの人は 高龄になってもこの傾向を持ちつづけている. 一方で加 歯による生理的变化 ${ }^{1,2)}$ や食経験の積み重ねにより食嗜 好は変化し ${ }^{3,4)}$ ，甘味に対する好みに質的な变化が見ら れるようになる.
異なった年齢層を対象とし横断的に糖溶液の嗜好を研 究した事例は, 海外におけるものがほとんどであり, 小 児や青年および高齢者は, より濃い甘味を好むことが報 告されている ${ }^{5 \sim 7)}$. 性差については, 男性の方が濃度の 濃い蔗糖溶液を好むという報告8), さらには性による相 違はないとする報告 ${ }^{9,10)}$ がある. 一方女児の方が男児よ り甘いミルクを好むという報告11)もある. これらの研究 
報告は，方法や対象年齢の相違のため，矛盾した結果で あると一概には考えられない，性差について明らかにす るためには，検查条件等を考慮した研究のさらなる積み 重ねが必要である．国内に拉いては，糖溶液の嗜好に焦 点をあて異なった年齢層や性を対象とした研究12) は数少

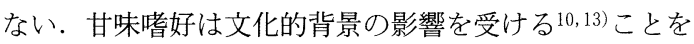
考慮すると, 国内に抢ける研究の蓄積も必要である.

これまでのところ甘味喍好の研究は具体的な食品に対 する好久の調査や，甘味の異なる食品に対する好みの調 査を中心に行なわれてきた $310,13,14)$. 一方 Tuorila ら ${ }^{9)}$ は，若年層の男女を対象に，甘味に対する認知と感情に 注目した質問紙調査を行い, 甘味強度の異なるソフトド リンクに対する官能検査結果と比較しながら甘味喍好に ついて検討している.

官能検査では，甘味刺激に対する反応（好み）を見る ことができるが，この反応は認知の過程が関与する複合 的な感情である15)。甘味は生理的，心理的満足感をもた らすものとして肯定的に認知される側面を持つ一方, 健 康への懸念などから否定的に認知される側面を持つ 16,17)。質問紙調査により甘味嗜好に関わる認知過程の一 端をとらえ，官能検査による反応結果と関連づけて調査 することは，甘味嗜好を究明する上で有用であると考え る.

本研究では調査対象を中学生および成人層とし, 官能 検査によって糖溶液に対する好みの年齢による差と，中 学生抢よび若年層の男女に扔ける性差を調べた．同時に 基本的な心理機能である甘味や甘い物に対する感情と認 知や好み，摂取を問う質問紙調査を行い，濃度や質の異 なる糖溶液の好みとの関係について検討した。

\section{2. 方 法}

\section{(1) 対象および時期}

広島県在住の 12 歳以上の男女 290 名に官能検査を実施 し，同じ対象者にその場で質問紙調査を行なった，対象 者の内訳は, 中学生 (12 15歳: 男 37 人, 女 46 人), 若 年層（18 29歳：男 48 人，女 53 人), 中年層前半 (30 39 歳: 男女 35 人), 中年層後半 ( $40 \sim 49$ 歳: 男女 34 人), 高年層（60歳以上：男女 37 人）であった. 50 歳代はデー タ数が少ないため分析の対象から除いた.

調査期間は，2000年11月から12月であった.

\section{(2) 官能検査}

1) 試料蔗糖 (片山化学, 試薬特級), キシリトー ル (日研化学), エリスリトール (日研化学) を蒸留水 に溶解させ試料液を作成した。
濃度の異なる蔗糖溶液として，4 種類 $(2.5 \%, 5.0 \%$, 10.0\%，20.0\%）を準備した．質の異なる桾溶液として, $15.0 \%$ 蔗糖溶液並びにこれと同じ甘味度を持つ 2 種類の 糖溶液, $15.17 \%$ キシリトール溶液 (以下 X溶液), $19.31 \%$ エリスリトール溶液（以下E溶液）と $15.17 \%$ キ トリトール溶液の 3 対 1 混合溶液 (以下 $\mathrm{E} / \mathrm{X}$ 混合溶液) を準備した， E / X 混合溶液は， E 溶液が示す後味のイ ガイガ感を抑制するために, $1 / 4$ 量のX溶液を加えた. なお，X溶液および $\mathrm{E}$ 溶液の甘味度は，渡辺の報告18)を 参考にしてPauli の全系列法によって調べ，15.0\%蔗楉 溶液と等甘味になる濃度を算出した. 3 種類の溶液のう ち 2 種類ずつの組み合わせ 3 通りを用い， 3 種類の各溶 液間の識別が可能であることを 3 点識別法によって確認 した.

2 ) 手順 溶液は容積 $25 \mathrm{~m} l$ の白色プラスチックカ ップに $10 \mathrm{~m} l$ ずつ注ぎ分けた，濃度の異なる蔗糖溶液の 検査と質の異なる糖溶液の検査の前には，必ず口をすす ぐように指示した。

濃度の異なる蔗糖溶液の検査では, 薄い万から順に上 昇系列的に一口ずつ飲むように指示し，好きな順に 1 位 から 4 位をでを答えさせた. 1 位 4 点, 2 位 3 点, 3 位 2 点, 4 位 1 点として点数化し, 嗜好順位得点とした.

質の異なる糖溶液の検査では, ランダムに試料を提供 し，好きな順に 1 位から 3 位までを答えさせた． 1 位 3 点, 2 位 2 点, 3 位 1 点として点数化し, 墸好順位得点 とした。

検査は広島大学教育学部の調理実習室, 広島大学付属 中学校抢よび広島県立祇園北高等学校の家庭科室, 東広 島市, 尾道市の公民館の 1 室などで， 1 人ずつ個別に室 温下で行なった。

\section{(3) 質問紙調查}

調査項目は, 年齢, 性別, BMI 值の他に表 1 に示し たように, ダイエット志向 1 項目, 食傾向 3 項目（好き な味付けの程度, 甘い物と自己認識の距離, 食べること は楽しいと感じる程度), 甘味莻好 6 項目（甘味や甘い 物に対する感情・認知・好み・摂取）とした。BMI 值 は横軸に身長，緃軸に体重を示したグラフを提示し，標 準よりやせている (19.8未満)，太っている（25.0以上） とその中間（19.8以上 25.0 未満）の 3 領域のいずれに属 するかを回答させた.

好きな味付けを問う設問については，「とても濃い味」 （7点）から「とても薄い味」(1点）までに，ダイエッ 卜志向を問う設問については「すごく減らしたい」（7 点）から「すごく増やしたい」（1点）までに対応した

$100(24)$ 
表 1 質問紙調査の設問内容

\begin{tabular}{|c|c|c|}
\hline 設問項目 & & 設 問 \\
\hline $\begin{array}{l}\text { 甘味嗜好a) } \\
\text { 甘味や甘い物に対する感情 }\end{array}$ & $\begin{array}{l}\text { 肯定的 } \\
\text { 否定的 }\end{array}$ & $\begin{array}{l}\text { 甘い物があるとうれしい. } \\
\text { 甘い物を食べないよう心がけることはよいことである. }\end{array}$ \\
\hline 甘味や甘い物に対する認知 & $\begin{array}{l}\text { 肯定的 } \\
\text { 否定的 }\end{array}$ & $\begin{array}{l}\text { 甘味は疲れをいやす. } \\
\text { 甘味は肥満の原因である. }\end{array}$ \\
\hline 甘い物に対する好み & & 甘い物好きである. \\
\hline 甘い物の摂取 & & 甘い物をよく食べる. \\
\hline $\begin{array}{l}\text { 食傾向 } \\
\text { 好きな味付けの程度 } \\
\text { 甘い物と自己認識との距離 }\end{array}$ & & $\begin{array}{l}\text { 濃い味付けが好きですか, 薄い味付けが好きですか.b) } \\
\text { 甘い物を食べるのは自分らしくない. } \\
\text { 食べることは楽しい. }\end{array}$ \\
\hline ダイエット志向 & & 自分の体重を減らしたいですか，増やしたいですか、c \\
\hline
\end{tabular}

a）甘い物や甘味に肯定的であるほど, 高得点になるよう点数化した.

b）濃い味好みほど高得点になるよう点数化した.

c）ダイエット志向が高いほど高得点になるよう点数化した.
行なった。

表 1 の設問各々に対す る回答を $1 \sim 7$ 点に得点 化したものを用いて，L 群 ( $1 \sim 3$ 点の回答者), M群 ( 4 点の回答者), $\mathrm{H}$ 群 ( $5 \sim 7$ 点の回答者) に分けた．BMI 值は標準 よりやせている, 太って いるとその中間の 3 領域 のいずれに属するかの 3 群を利用した。これらの 3 群を独立変数とし, 官 能検査の嗜好順位得点を 従属変数として一元配置 の分散分析を行なった。

分散分析の結果，有意差のある場合は下位検定，すな わちチューキーの HSD 検定または LSD 検定を行なっ た ${ }^{19)}$. 統計処理にはSTATISTICA（スタットソフトジ ヤパン物）を用いた。

\section{3. 結果と考察}

答は得点を反転させ，甘味に対して肯定的であるほど高 得点になるようにした。

なお BMI 值とダイエット志向を問う設問は，思春期 であることを考慮して, 中学生に対する質問から除いた。

\section{(4) 分析方法}

年齢層 5 群（中学生，若年層，中年層前半，中年層後 半，高年層）を独立変数とし，濃度や質の異なる糖溶液 の嗜好順位得点を従属変数として, 一元配置の分散分析 を行なった．また男女のデータ数が確保されている中学 生と若年層を分析対象として, 年秢層 2 群（中学生, 若 年層) と性を独立変数とし，濃度や質の異なる糖溶液の 搘好順位得点を従属変数として, 二元配置の分散分析を り，中年層前半（30歳代）をピークに低下した. $10.0 \%$

\section{（1）官能検査}

1）年齢による相違 4 種の蔗糖溶液濃度におけ る各年齢層の嗜好順位得点の平均值と下位検定結果を表 2 に示した. 一元配置の分散分析の結果，すべての蔗糖 溶液濃度において年齢の相違による差は有意であった。

$2.5 \%$ 蔗糖溶液では, 中学生は中年層前半に比べて, 有意に嗜好順位得点の平均值が低かった． $5.0 \%$ 蔗糖溶 液においても, 中学生は若年層と中年層前半に比べて, 有意に平均值が低かった． $2.5 \% ， 5.0 \%$ 蔗糖溶液の平均 值は中年層前半までは年歯層が上がるにつれて高くな 蔗糖溶液は, 中学生の平均 值が高く，中学生と中年層 前半の間に有意差があった. $20.0 \%$ 蔗糖溶液は中学生の 平均值が最も高く, 中年層 前半, 中年層後半の群が低 くなり, 中学生と中年層と の間には有意差があった.

以上のように, 中学生と 中年層前半には全ての蔗糖

(25) 101 
濃度で有意差が見られた。 中学生は他の年㱓層に比べて 濃い甘味を好むことが明らかである。

Cess ら ${ }^{7}$ は，20〜25歳の成人が14〜16歳の青年よりも 低濃度（4.8\%）の蔗糖を好むこと，10.0\%蔗糖溶液に 対する青年と成人の好みの差は縮小すること, 青年は成 人よりも高濃度 $(20.8 \%)$ の蔗糖溶液を好んでいること を示した. Desor ${ }^{5)}$ は $0.075 \sim 0.600 \mathrm{M}$ の蔗糖溶液の内, 最も好きな濃度を選ぶ検査によって縦断的な研究を行 い, 11〜 15歳の時よりも19〜25歳の時の方がより濃度の 低い甘味を好む傾向にあることを報告している。また

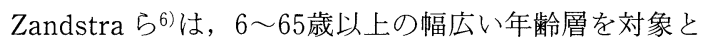
して蔗糖溶液の好みを調べ, 小児と高齢者は濃度が高い ほど好みの評点が高くなることを報告している．これら 一連の研究報告は, 本研究の結果と傾向が一致しており, 糖溶液に対する嗜好の加齢变化は, 社会的·文化的影響 を受け難いヒトの生理的特徵であることを示唆してい る.

全年齢層において嗜好得点が最も高いのは5.0\%蔗糖 溶液濃度であり，次いで $10.0 \%, 2.5 \%, 20.0 \%$ の順に 高かった. Yamaguchi ら 20 は20〜40歳の男女は8.56\% の蔗糖溶液を最も好をしいと感じ，34.5\%で好むしくな いと感じたと報告している. また, 加藤21)は19〜22歳の 女子学生では $8.5 \%$ か $59.0 \%$, 坂元ら ${ }^{22)}$ は $18 \sim 20$ 歳の 女子学生では $7.0 \%$ から $13.8 \%$ の濃度範囲の蔗糖溶液が 好まれたと報告している. 今回の結果をこれらの報告と 比較すると, 年齢が対応する若年層と中年層では, やや

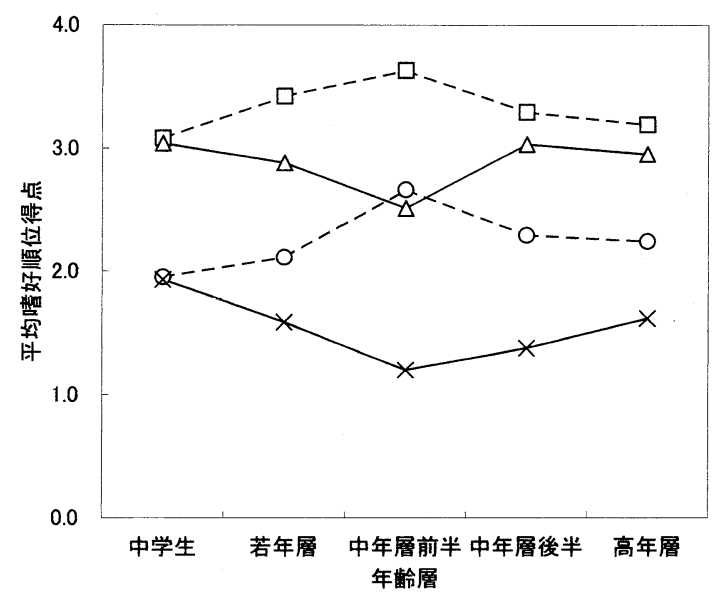

図 1 濃度の異なる蔗糖溶液に対する各年齢層の平均嗜好順位 得点

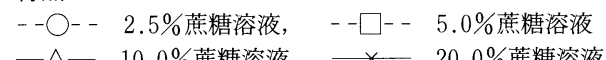

低い濃度の蔗糖溶液が好まれていた。これには，尺度の 構成, 刺激の提示方法, 分析方法の相違が影響している と考えられる.

$5.0 \%$ 蔗糖溶液が全年齢層に最も好まれていたが，他 の濃度の蔗糖溶液の好まれ方には年齢差がみられた。低 濃度 $(2.5 \%, 5.0 \%)$ 蔗糖溶液の搘好得点は中年層前半 である30歳代にピークを持つ山型を示すのに対し, 10.0 \%蔗糖溶液は年齢層に差が多少あるものの, 広い年齢層 で比較的高い嗜好得点を示し好まれており，中でも中学 生と中年層後半に好まれていた． $20.0 \%$ 蔗糖溶液は全体 的に赀好得点が低く, 特に中年層前半では好まれていな かった（図1）。

以上のことから30歳代前半に甘味喍好の分岐点の存在 が推察できる. 即ち中学生は濃い甘味を好み薄い甘味を 好をない傾向を持つが，加齢と共に次第に薄い甘味を好 み濃い甘味を避けるようになり，30歳代を境に再び濃い 甘味を好む傾向に転じる，高橋らの食品の嗜好に関する 研究23)では, 30 歳代と40歳代の間に食品の好みの変化域 があると推察されている. 特に甘味因子に関しては, 10 歳代と20歳代で「好き」の割合が多く,30歳代から「嫌 い」の割合が多くなると報告されている．30歳代を転機 に甘味に対する嗜好が変化する点では本研究と一致した 傾向が見られる，一方我々の研究では, 高年層で高濃度 の蔗糖溶液を好む傾向が現れるが，高橋らの報告21)では 高年層での甘味食品への嗜好は低いままとなっている. 食品には味覚に関わる要因以外に, 料理様式や食感など の様々な因子が混在しており，それらが莻好判定に影響 を与える、そのため甘味溶液を実際に味わって判断する 場合とは，異なると考えられる.

質の異なる糖溶液の嗜好順位得点に関しては, 分散分 析の結果, 年齢層の違いによる有意差は見られなかった ので, データは省略した.

2 ) 中学生と若年層 年齢と性を独立変数とした 二元配置分散分析の結果, $2.5 \%$ 蔗糖溶液では男女間に, $5.0 \%$ と $20.0 \%$ 蔗糖溶液では年齢層間に有意差が見られ た（表 3 ).

$2.5 \%$ 蔗糖溶液では, 女性は男性よりもこれを好んで いた. 男女別の嗜好順位得点を比較すると, 女性は男性 よりも濃度の低い甘味を好み, 濃度の高い甘味を好まな い傾向が見られた。

これまでの蔗桾溶液における研究では, 甘味の好みに は男女差は無いとする報告9,10), 男性のほうが濃い甘味 を好むという報告8)がなされており，一致した見解は得 られていない。蔗糖溶液の設定濃度, 被験者数や年齢の

$102(26)$ 
表 3 中学生, 若年層男女の蔗糖溶液に対する平均嗜好順位得点とチューキーの HSD 検定結果

$(\mathrm{M} \pm$ S.D. $)$

\begin{tabular}{|c|c|c|c|c|c|c|c|c|c|c|c|c|}
\hline \multirow[b]{3}{*}{ 年齢層 } & \multicolumn{12}{|c|}{ 蔗糖溶液の濃度（\%） } \\
\hline & \multicolumn{3}{|c|}{2.5} & \multicolumn{3}{|c|}{5.0} & \multicolumn{3}{|c|}{10.0} & \multicolumn{3}{|c|}{20.0} \\
\hline & 男 & 女 & 男女 & 男 & 女 & 男女 & 男 & 女 & 男女 & 男 & 女 & 男女 \\
\hline 中学生 & $1.73 \pm 0.96$ & $2.13 \pm 1.17$ & $1.95 \pm 1.09$ & $3.16 \pm 0.80$ & $3.02 \pm 0.88$ & $3.08 \pm 0.84$ & $3.11 \pm 0.91$ & $2.98 \pm 0.93$ & $3.04 \pm 0.92$ & $2.00 \pm 1.03$ & $1.87 \pm 1.02$ & $1.93 \pm 1.02$ \\
\hline 若年層 & $1.96 \pm 1.01$ & $2.25 \pm 1.04$ & $2.11 \pm 1.03$ & $3.31 \pm 0.78$ & $3.51 \pm 0.75$ & $3.42 \pm 0.77$ & ${ }_{2.96 \pm 0.82}^{* *}$ & $2.81 \pm 0.83$ & $2.88 \pm 0.83$ & $1.77 \pm 1.04$ & $1.43 \pm 0.64$ & $1.59 \pm 0.86{ }^{*}$ \\
\hline 全年齢層 & $1.86 \pm \underbrace{0.99}_{*}$ & $\stackrel{2.19 \pm 1.09}{\longrightarrow}$ & $2.04 \pm 1.06$ & $3.25 \pm 0.79$ & $3.28 \pm 0.85$ & $3.27 \pm 0.82$ & $3.02 \pm 0.86$ & $2.89 \pm 0.88$ & $2.95 \pm 0.87$ & $1.87 \pm 1.03$ & $1.63 \pm 0.86$ & $1.74 \pm 0.95$ \\
\hline
\end{tabular}

$*: \mathrm{p}<0.05, * *: \mathrm{p}<0.01, * * *: \mathrm{p}<0.001$

分布などの実験条件の相違や, 異なった文化圏での研究 であることが，一定の傾向を得にくい背景にあると考え られる.

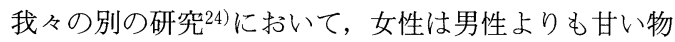
に肯定的な感情を持ち，甘い物を好み，購入し摂取する 程度が高いにもかかわらず，甘い物に対して肯定的なイ メージのみではなく否定的なイメージを持ち，甘い物に 対する認知の程度が強いことが示された，男性に比較し て低甘味の蔗糖溶液を好み, 高甘味の蔗糖溶液を避ける 傾向は，甘い物に対する否定的なイメージが影響してい る可能性が考えられる.

$5.0 \%$ と $20.0 \%$ 蔗糖溶液においては，中学生と若年層 との間に有意差が見られた．他の年㱓層を含めた分散分 析結果（表 2 ）とは5.0\%蔗糖溶液での有意水準が異な り，20.0\%蔗糖溶液で有意差が見られた点が異なるが， これは対象としたデータ構造の相違のためである.

質の異なる糖溶液の嗜好順位得点に関しては, 年齢, 性の違いによる差は有意ではなかった.

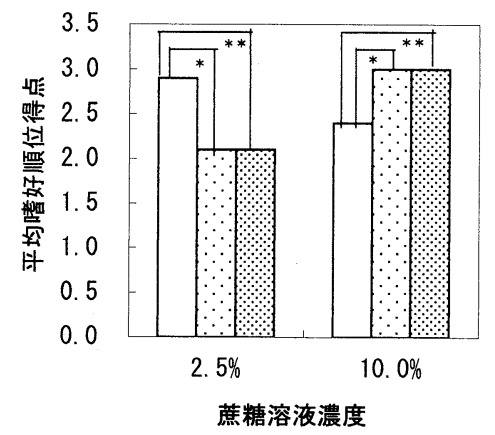

図 2 「甘い物があるとうれしいと感じる程度」と2.5\%， $10.0 \%$ 蔗糖溶液に対する平均嗜好順位得点

L群（うれしいと感じる程度が低い群）：

M群（うれしいと感じる程度が中程度の群）

H群（うれしいと感じる程度が高い群）:

* : $\mathrm{p}<0.05, * *: \mathrm{p}<0.01$

\section{（2）官能検査と質問紙調査}

甘味嗜好, 食傾向の相違は蔗糖溶液濃度および質の異 なる糖溶液に対する好みと関連していた. 図 2 図 8 に 分散分析の結果, 有意な差の見られたデータのみを示し た。

1) 甘味や甘い物に対する感情 ·認知 ·好み・甘い 物の摂取之蔗糖濃度の好みとの関係＼cjkstart図 2 に感情「甘 い物があるとうれしい程度」で分けた群の，2.5\%， $10.0 \%$ 蔗糖溶液における嗜好順位得点を示した．うれし いと感じる $\mathrm{H}$ 群および $\mathrm{M}$ 群は $10.0 \%$ 蔗糖溶液を好み,

L 群は $2.5 \%$ 蔗糖溶液をより好んでいた。図 3 に感情 「甘い物を食べないよう心がけることはよいことである と感じる程度」で分けた群の $2.5 \%$ 蔗糖溶液における嗜 好順位得点を示した. 食べないよう心がけることを肯定 する $\mathrm{H}$ 群は， $2.5 \%$ 蔗糖溶液を好んでいた。 認知（「甘 い物は肥満の原因である」，「甘い物は疲れをいやす」） の相違による有意な差は見られなかった。

図 4 に好み「甘い物好きの程度」で分けた群の $2.5 \%$

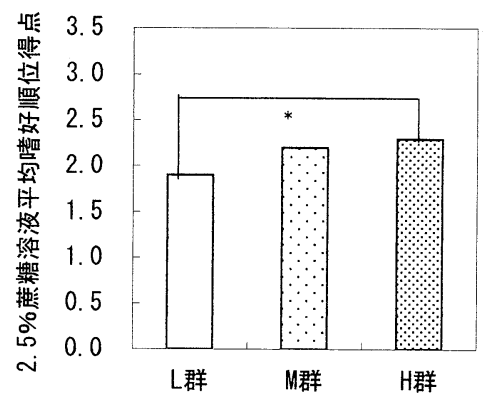

図 3 「甘い物を食べないよう心がけることはよいことであると 感じる程度」と2.5\%蔗糖溶液に対する平均嗜好順位得点 L 群（よいことであると感じる程度が低い群）：

M群（よいことであると感じる程度が中程度の群） H群（よいことであると感じる程度が高い群）： * : $\mathrm{p}<0.05, * *: \mathrm{p}<0.01$ 


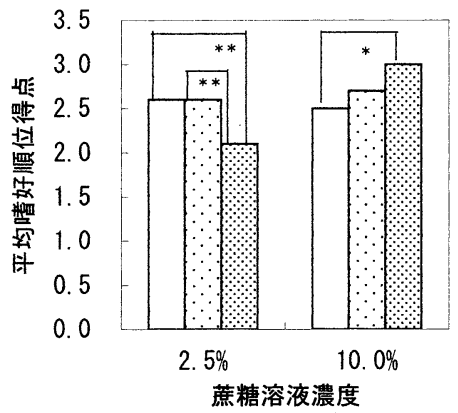

図 4 「甘い物好きの程度」と2.5\%，10.0\%蔗糖溶液に対する 平均嗜好順位得点

L 群（甘い物好きの程度が低い群）：

M群（甘い物好きの程度が中程度の群）：

H群（甘い物好きの程度が高い群）：

*: $\mathrm{p}<0.05, * *: \mathrm{p}<0.01$

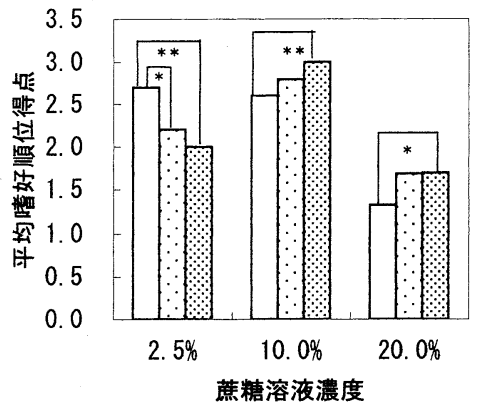

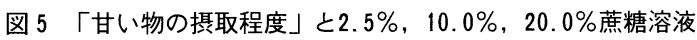
に対する平均嗜好順位得点

L 群（摄取程度が低い群）：

M群（摂取程度が中程度の群）:

$\mathrm{H}$ 群（撖取の程度が高い群）：

$*: \mathrm{p}<0.05,{ }^{* *}: \mathrm{p}<0.01$

と $10.0 \%$ 蔗糖溶液における嗜好順位得点を示した。甘い 物好きの $\mathrm{H}$ 群は $10.0 \%$ 蔗桾溶液を好み， M, L 群は 2.5 \%蔗糖溶液を好んでいた。

図 5 に甘い物を摄取する程度で分けた群の $2.5 \%$, $10.0 \%$ と $20.0 \%$ 蔗糖溶液に抢ける喏好順位得点を示し た、甘い物をよく摂取するH群は $10.0 \%$ と $20.0 \%$ 蔗糖溶 液を好み, 摄取程度の低い $\mathrm{L}$ 群は $2.5 \%$ 蔗糖溶液を好九 でいた。

以上のことから好みの蔗糖溶液濃度の選択には, 甘味 に対する認知ではなく感情が影響していること，また甘 い物好きである程度や甘い物を摂取する程度も濃度の選 択に関連していることが示された。

2) BMI 值, ダイエット志向, 食傾向之蔗糖濃度の 好みとの関係 図6 に食傾向の設問項目である好きな

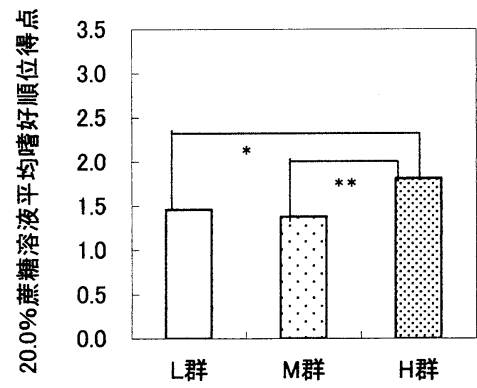

図 6 「好きな味付けの程度」と20.0\%蔗糖溶液に対する平均嗜 好順位得点

L 群（薄味好みの群）：

M群（どちらでもない群）

$\mathrm{H}$ 群（濃い味好みの群）:

* : $\mathrm{p}<0.05, * *: \mathrm{p}<0.01$

味付けの程度で分けた群の，20.0\%蔗糖溶液における嗜 向順位得点を示した．濃い味好みの $\mathrm{H}$ 群は $\mathrm{M}$ 群抢よび $\mathrm{L}$ 群に比較して，20.0\%蔗糖溶液のような濃い溶液を好ん でいた．好きな味付けが濃いほど甘い物の摂取程度が高 いという結果を我々の他の研究24)で得ており，好きな味 付けと甘味嗜好とは比較的関連が強いと判断できる.

BMI 值，ダイエット志向，甘い物と自己認識の距離， 食べることは楽しいと感じる程度の相違による差は有意 ではなかった。これらの項目と蔗桾溶液濃度の好みとの 関連については，現時点でいずれとも判断できない。一 方, 認知過程を含めた甘味嗜好を調べた我々の研究では, ダイエット志向や甘い物と自己認識の距離，食に対する こだわりと甘味嗜好との間に相関が見られた年，。蔗糖 溶液濃度の好みは，質問紙調査で調べた甘味嗜好とは必

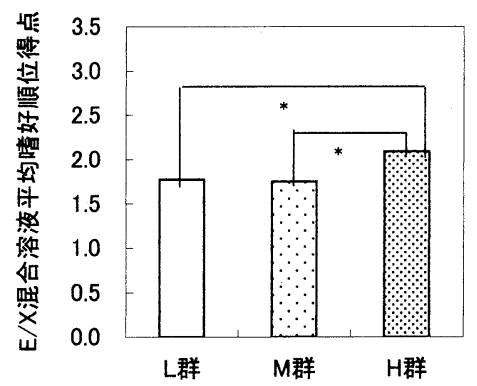

図 7 「好きな味付けの程度」と $\mathrm{E} / \mathrm{X}$ 混合溶液に対する平均嗜 好順位得点

L 群 (薄味好みの群)：

M群（どちらでもない群）

$\mathrm{H}$ 群（濃い味好みの群）:

$*$ : $\mathrm{p}<0.05, * *: \mathrm{p}<0.01$

$104(28)$ 


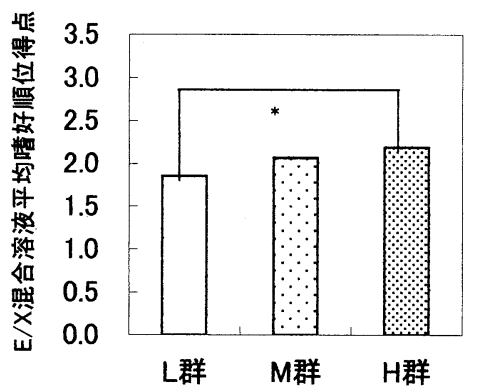

図 8 「い物を食べることは自分らしくないと感じる程度」と $E / X$ 混合溶液に対する平均嗜好順位得点

L群（自分らしくないと感じる程度が低い群）：

M群（自分らしくないと感じる程度が中程度の群）：

$\mathrm{H}$ 群（自分らしくないと感じる程度が高い群）：

$*: \mathrm{p}<0.05, * *: \mathrm{p}<0.01$

ずしも対応しないと考えられる.

3）質問紙調査項目亡質の異なる糖溶液の好みとの 関係図 7 に好きな味付けの程度で分けた群の, E/ $\mathrm{X}$ 混合溶液における嗜好順位得点を示した。濃い味好 みの $\mathrm{H}$ 群は $\mathrm{M}$ 群および $\mathrm{L}$ 群に比較して $\mathrm{E} / \mathrm{X}$ 混合溶液 を好んでいた。

図 8 に甘い物と自己認識の距離で分けた群の, E / X 混合溶液に対する嗜好順位得点を示した。甘い物を食べ ることは自分らしくないと考える $\mathrm{H}$ 群は, E / X 混合 溶液を好んでいた。

蔗糖溶液, X溶液, E / X 混合溶液の好みに対する BMI 值, ダイエット志向, 甘味や甘い物に対する感情 . 認知・好み・摂取程度の相違による差は有意ではなかっ た。

3 種類の糖溶液のうち, $\mathrm{E} / \mathrm{X}$ 混合溶液についてのみ 回答による群分けに対応した差が見られた。 E 溶液の甘 味質は，あっさりとした後引きのない味質であることが 報告されている25,26). また本研究の官能検査において, 口腔内に含んだ直後の $\mathrm{E}$ 溶液の甘味の強さが被験者よ り報告されており，特徵的な甘味質であるといえる. 濃 い味好みの者は，E／X混合溶液を口に入れた直後の甘 味の強さを評価し，甘い物を食べることは自分らしくな いと感じる者は, E / X 混合溶液の甘味が後に引かない ことを評価した可能性が考えられる.しかしこれらの点 を明確にするには，糖溶液の組成を含めてさらに検討す る必要があろう。

\section{4. 要 約}

濃度や質の異なった甘味溶液の好みを調べると共に，
甘味や甘い物に対する感情・認知・恸取などの質問紙調 査回答との関係についても検討した. 調査対象は中学生 および成人の幅広い年㱓層とし, 中学生および若年層で は性差を含めて分析した。

（1）全年齢層で $5.0 \%$ 蔗糖溶液の嗜好順位得点が最も 高く, 次いて $10.0 \%, 2.5 \%, 20.0 \%$ の順に好まれてい たが，好まれ方には年龄層による相違があった。

（2）中学生は中年層前半に比較して, 高濃度蔗糖溶液 $(10.0 \% ， 20.0 \%)$ における嗜好順位得点が高く，低濃 度蔗糖溶液（2.5\%，5.0\%）では低かった。

（3）低濃度蔗糖溶液（2.5\%，5.0\%）の嗜好順位得点 は30歳代にピークを持つ山型を示し, 高濃度蔗桾溶液 （20.0\%）では，30歳代が谷型となったことから，蔗糖 溶液嗜好濃度の変化域が中年層前半に存在することが指 摘された.

（4）中学生と若年層では $2.5 \%$ 蔗糖溶液を, 女性が有 意に好んだ。

（5）蔗糖溶液濃度の好みには，甘味に対する認知では なく感情が影響していた．また蔗糖溶液濃度の好みは甘 い物に対する好み, 甘い物の摂取, 好きな味付けの程度 との間に関連が見られた.

（6）糖溶液の質に対する好みと，年齢や性との間には 関連はなかったが，好きな味付けや甘い物と自己認識の 距離との間には関連が示された.

本研究を進めるにあたり番本正和校長ならびに国本洋 美教諭 (広島県立祇園北高等学校), 一八瀬孝恵教諭, 日浦美智代教諭 (広島大学付属中 ·高等学校), 濫觞克 子氏（東広島観光協会）に多大なご協力をいただいたこ とを深謝いたします。

\section{引用文献}

1) Drewnowski, A.: Sensory control of energy density at different life stages, Proceedings of the Nutrition Society, 59, 239-244 (1999)

2） A. W.ローグ, 木村 定訳 : 食の心理学, 青土社, 東京, 127-128 (1994)

3）長沼誠子：甘味嗜好の地域性, 日本食生活学会誌, 12, 9 -14 (2001)

4）川端晶子, 山本 隆: 食と感性, 光琳, 東京, 52 (1999)

5) Desor, J. A. : Longitudinal Changes in Sweet Preferences in Humans, Physiology and Behavior, 39, 639-641 (1987)

6) Zandstra, E H. and de Graff, C. : Sensory Perception and Pleasantness of Orange Beverages from Childhood to Old Age, Food Quality and Preference, 9, 5-12 (1998)

7) De Graff, C. and Zandstra, E H. : Sweetness Intensity and 
Plesantness in Children Adolescents and Adults, Physiology and Behavior, 67, 513-320 (1999)

8) Enns, M. P., Van Itallie, T.B. and Grinker, J. A. : Contributions of Age, Sex and Degree of Fatness on Preferences and Magnitude Estimations for Sucrose in Humans, Physiology and Behavior, 22, 999-1003 (1979)

9) Tuorila, H. and Mahlamaki S : The Relationship of Attitudes and Experiences of Finish Youths to their Hedonic Responses to Sweetness in Soft Drinks, Appetite, 31, 115124 (1985)

10) Holt, S. H. A, Cobiac, L, Bcaumont-Smith, N. E, Easton, K, Best, D. J. : Dietary habits and the perception and liking of sweetness among Australian and Malaysian students : A cross-cultural study, Food Quality and Preference, 11, 299$312(2000)$

11) Nisbett, E. R. and Gurwitz, B. S. : Weight, Sex, and the Eating Behavior of Human Newborns, J. Comp. and Physiol. Psychology, 73, 245-253 (1970)

12）三浦春恵：甘味に対する味覚喏好性について, 調理科学, 2, 85-91 (1969)

13) Perscott, J., Bell, G. A., Gillmore R., Yoshida, M., O'Sullivan, M., Korac, S., Allen, S. and Yamazaki, K. : Cross'cultural Comparison of Japanese and Australian Responses to Manipulations of Sweetness in Foods, Food Quality and Preference, 8, 45-55 (1996)

14）加藤征恵, 永田佳子, 井川明美 : 大学生の塩味または甘味 に対する味覚意識と食物嗜好, 調理科学, 25, 39-46（1985）

15）今田純雄, 長谷川智子, Rozin, P., : 塩味嗜好の獲得に関 する行動発達学的研究, 平成 7 年度助成研究報告集（ソルト
・サイエント研究財団), 33-44 (1996)

16）渡辺 茂, 古屋 泉: チョコレートの観かた・感じかた, 食の科学, 252，22-29（1999）

17）足立己幸 :「砂糖」，女子栄養大学出版部，東京，230-233 (1979)

18）渡辺長男：結晶葡萄糖（Dextrose-monohydrate）の甘味 度について，澱粉糖技術研究会報， 14，44-50（1955）

19）森 敏昭, 吉田寿夫 : 心理学のためのデータ解析テクニカ ルブック，北大路書房，京都，170（1990）

20) Yamaguchi, S. and Takahashi, C.: Hedonic Functions of Monosodium Glutamate and Four Basic Taste Substances Used at Various Concentration Levels in Single and Complex Systems, Agricultural and Biological Chemistry, 48, 10771081 (1984)

21）加藤征恵 : 女子学生の塩味と甘味に対する味覚感受性と味 嗜好について，家政誌，43，1209-1215（1992）

22）坂元明子, 山下純子, 山口伸枝 : 単一味における好みの中 心と限界について（2), 日本食生活学会誌，8，40-47 (1997)

23）高橋史人, 山口和子 : 食品の嗜好に関する研究（第 3 報） 一年齢階層, 地域の㫮好の特徵一, 調理科学, 18, 259-278 (1985)

24）加藤佳子, 井川佳子 : 年齢や性の相異による甘味喍好の特 徵, 投稿中

25）青山佐喜子, 高田修代, 藤原耕三 : エリスリトールの甘味 質と調理への利用，調理科学，25，8-14（1992）

26）早川幸雄 : 糖アルコールの新知識, 食品化学新聞社, 東京, 72-73 (1996) 